\title{
IMPLEMENTASI MODEL STAD DALAM MENINGKATKAN HASIL BELAJAR SIWA
}

\author{
Esminarto $^{1}$, Sukowati $^{2}$, Nur Suryowati ${ }^{3}$, Khoirul Anam $^{4}$ \\ ${ }^{1,2}$ SDN Ngasem Kediri, ${ }^{3}$ SDN Badar 2 Kediri, ${ }^{4}$ SDN Gogorante \\ Email: ${ }^{1}$ isminartoisminarto@gmail.com, ${ }^{2}$ suryowa@gmail.com, \\ ${ }^{3}$ sitipatimah844@gmail.com, ${ }^{4}$ khoirul6301@yahoo.com.
}

\begin{abstract}
ABSTRAK: Pembelajaran yang dilakukan seharusnya menyenangkan bagi siswa sehingga dapat meningkatkan motivasi belajar siswa sehingga ikut meningkatkan hasil belajar pada siswa. Kenyataanya sebagian guru lebih suka menerapkan model pembelajaran konvensional. Model pembelajaran cooperative tipe STAD menjadi salah satu solusi untuk mengatasi hal tersebut. STAD (Student Team Achievement Division) adalah pembelajaran kooperatif yang paling sederhana, dan merupakan pembelajaran kooperatif yang cocok digunakan untuk mengaktifkan siswa. Hasil dari penerapan STAD yang dilakukan oleh guru adalah STAD dapat meningkatkan hasil pembelajaran pada siswa.
\end{abstract}

\section{Kata Kunci: STAD, Hasil Belajar}

Seorang guru diharapkan dapat menciptakan lingkungan belajar yang dapat meningkatkan keterlibatan siswa secara langsung dan bertanggung jawab terhadap belajar itu sendiri, karena belajar dapat diperoleh ke arah yang baik, jika siswa harus mau belajar sebaik mungkin. Belajar dengan baik dapat diciptakan apabila guru dapat mengorganisir belajar siswa, sehingga minat dan motivasi siswa dapat ditumbuhkembangkan dalam suasana kelas yang menggairahkan dengan berbagai variasi dan model pembelajaran. Kenyataanya sebagian guru lebih suka menerapkan model pembelajaran konvensional, yang pertukaran informasinya lebih bersifat satu arah, guru lebih sering berperan sebagai narasumber sementara siswa sebagai pendengar (penerima informasi) yang pasif. Model pembelajaran ini menetapkan guru sebagai inti dalam keberlangsungan proses belajar mengajar. Siswa dianggap memiliki minat, kecakapan, kepentingan belajar dan kesiapan belajar yang sama. Siswa tidak diberi kesempatan banyak untuk mengungkapkan pendapat dan berdiskusi dengan siswa lainnya.

Siswa adalah manusia yang memiliki keunikan dan keragaman. Oleh karenya guru harus merubah paradigma dalam pembelajarannya. Seiring perkembangan jaman mulai berkembang pembelajaran yang terpusat kepada siswa. Siswa dituntut aktif untuk mencari dan menemukan materi bersama dengan guru dan teman-temannya. Sehingga perlu dipilih model pembelajaran yang dapat mengembangkan keaktifan siswa. Model pembelajaran perlu dipahami guru agar dapat melaksanakan pembelajaran secara efektif dalam meningkatkan hasil pembelajaran. Di dalam penerapannya, model pembelajaran harus dilakukan sesuai dengan kebutuhan siswa 
karena masing-masing model pembelajaran memiliki tujuan, prinsip, dan tekanan utama yang berbeda-beda.

Menurut Joyce dan Weil dalam Rusman (2012) model-model pembelajaran sendiri biasanya disusun berdasarkan berbagai prinsip atau teori pengetahuan. Para ahli menyusun model pembelajaran berdasarkan prinsip-prinsip pembelajaran, teoriteori psikologis, sosiologis, analisis sistem, atau teori-teori lain yang mendukung. Joyce \& Weil berpendapat bahwa model pembelajaran adalah suatu rencana atau pola yang dapat digunakan untuk membentuk kurikulum, merancang bahan-bahan pembelajaran, dan membimbing pembelajaran di kelas atau yang lain. Model pembelajaran dapat dijadikan pola pilihan, artinya para guru boleh memilih model pembelajaran yang sesuai dan efisien untuk mencapai tujuan pembelajarannya.

Pembelajaran kooperatif adalah suatu pembelajaran yang membuat siswa membentuk kelompok-kelompok kemudian melakukan kegiatan belajar bersamasama dalam setiap kelompok tersebut untuk mencapai suatu tujuan. Pembelajaran kooperatif dapat mengubah pola pikir individual menjadi pola pikir yang peduli dengan orang lain, dalam hal ini adalah teman satu kelompok. Dengan pembelajaran kooperatif siswa diharapkan dapat saling membantu, saling memberikan argumentasi, dan berdiskusi untuk menyelesaikan suatu permasalahan. Selanjutnya dengan pola interaksi tersebut siswa akan meningkat hasil belajarnya.

Pembelajaran kooperatif tidak sama dengan belajar kelompok. Menurut Rusman (2012) terdapat empat hal penting dalam pembelajaran kooperatif yakni adanya siswa dalam kelompok, adanya aturan main (role) dalam kelompok, adanya upaya belajar dalam kelompok, dan adanya kompetensi yang harus dicapai oleh kelompok. Selain itu, ada lima unsur dasar dalam pembelajaran kooperatif antara lain ketergantungan yang positif, pertanggungjawaban individu, kemampuan bersosialisasi, tatap muka, dan evaluasi kelompok. Tanpa semua itu, suatu pembelajaran tidak dapat disebut suatu pembelajaran kooperatif.

\section{PEMBAHASAN}

\section{Model Pembelajaran Cooperative}

Model yang tepat perlu diperhatikan relevansinya dengan tujuan pengajaran. Di dalam model pembelajaran cooperative terdapat beberapa variasi model yang dapat diterapkan, yaitu di antaranya: 1) Student Team Achievement Division (STAD), 2) Jigsaw, 3) Group Investigation (GI), 4) Rotating Trio Exchange, dan 5) Group Resume. Dari beberapa model pembelajaran tersebut model yang banyak dikembangkan adalah model Student Teeam Achievement Division (STAD) dan Jigsaw (Isjoni, 2010).

Pembelajaran cooperatif merupakan strategi belajar mengajar di mana siswa belajar dalam kelompok-kelompok kecil dengan tingkat kemampuan kognitif yang heterogen. (Woolfolk dalam Budiningarti 1998: 22) menyatakan bahwa pembelajaran kooperatif merupakan salah satu pembelajaran yang didasarkan pada paham konstruktivisme. Pada pembelajaran kooperatif siswa percaya bahwa keberhasilan mereka akan tercapai jika dan hanya jika setiap anggota kelompoknya berhasil. 
Sistem pengajaran yang memberi kesempatan kepada anak didik untuk bekerjasama dengan sesama siswa dalam tugas-tugas yang terstruktur disebut sebagai pengajaran gotong royong. Sistem pendidikan gotong royong merupakan alternatif menarik yang dapat mencegah timbulnya kegresifan dalam sistem kompetisi dan keterasingan dalam sistem individu tanpa mengorbankan aspek kognitif.

Pembelajaran kooperatif bergantung pada kelompok-kelompok kecil siswa. Meskipun isi dan petunjuk yang diberikan oleh guru merupakan bagian dari pembelajaran, namun pembelajaran kooperatif secara berhati-hati menggabungkan kelompok-kelompok kecil sehingga seluruh anggotanya dapat bekerja bersama untuk memaksimalkan pembelajaran dirinya dan pembelajaran satu sama lainnya. Masingmasing anggota kelompok bertanggungjawab untuk mempelajari apa yang disajikan dan membantu teman anggotanya untuk belajar. Ketika kerjasama ini berlangsung, tim menciptakan atmosfir pencapaian, dan selanjutnya pembelajaran ditingkatkan.

Pembelajaran kooperatif merupakan suatu pembelajaran kelompok dengan jumlah peserta didik 2-5 orang dengan gagasan untuk saling memotivasi antara anggotanya untuk saling membantu agar tercapainya suatu tujuan pembelajaran yang maksimal. Hal ini sejalan dengan Slavin (1995) yang menyatakan In cooperative learning methods, students work together in four member teams to master material initially presented by the teacher. Hal ini berarti cooperative learning atau pembelajaran cooperative adalah suatu model pembelajaran dimana sistem belajar dan bekerja kelompok-kelompok kecil berjumlah 4-6 orang secara kolaboratif sehingga dapat merangsang peserta didik lebih bergairah dalam belajar. Sehingga dapat dikatakan bahwa pembelajaran cooperative adalah cara belajar dalam bentuk kelompok-kelompok kecil yang saling bekerjasama dan diarahkan oleh guru untuk mencapai tujuan pembelajaran yang diharapkan.

\section{Model Cooperative Tipe STAD}

Salah satu pembelajaran cooperative adalah STAD (Student TeamsAchievement Division). Pembelajaran cooperative tipe STAD yang dikembangkan oleh Robert Slavin dan teman-temannya di Universitas John Hopkin (Slavin, 1995) merupakan pembelajaran kooperatif yang paling sederhana, dan merupakan pembelajaran kooperatif yang cocok digunakan oleh guru yang baru mulai menggunakan pembelajaran Cooperative. Model Pembelajaran coperatif tipe STAD merupakan pendekatan Cooperative Learning yang menekankan pada aktivitas dan interaksi diantara siswa untuk saling memotivasi dan saling membantu dalam menguasai materi pelajaran guna mencapai prestasi yang maksimal. Guru yang menggunakan STAD mengajukan informasi akademik baru kepada siswa setiap minggu mengunakan presentasi verbal atau teks.

STAD merupakan salah satu pembelajaran kooperatif yang paling sederhana dan sangat baik untuk guru pemula ketika ingin menerapkan pembelajaran kooperatif. STAD terdiri atas lima komponen utama yaitu presentasi kelas, pembentukan tim, kuis, skor kemajuan individual, dan rekognisi tim (Slavin, 1995). STAD merupakan salah satu model pembelajaran kooperatif yang memicu siswa bekerja sama untuk 
belajar agar mereka saling mendorong dan membantu satu sama lain dalam menguasai kompetensi yang diharapkan serta menumbuhkan kesadaran bahwa belajar itu penting, bermakna dan menyenangkan. Model ini juga sangat mudah diadaptasi, telah digunakan dalam Matematika, IPA, IPS, Bahasa Inggris, teknik dan banyak subjek lainnya, dan pada tingkat sekolah dasar sampai perguruan tinggi.

\section{Prinsip STAD}

STAD merupakan variasi pembelajaran kooperatif dengan membagi siswa menjadi kelompok secara heterogen beranggotakan empat-lima siswa dengan beragam kemampuan yang berbeda. Guru memberikan suatu penjelasan dan permasalahan kepada siswa di dalam kelompok dan memastikan bahwa semua anggota kelompok dapat menguasai permasalahan tersebut. Gagasan utama STAD adalah memacu siswa agar saling mendorong dan membantu satu sama lain untuk menyelesaikan masalah yang diberikan oleh guru. Jika siswa menginginkan kelompoknya memperoleh hadiah maka mereka harus membantu teman sekelompok dalam mempelajari pelajaran. Siswa diberi waktu untuk bekerja sama setelah pelajaran diberikan oleh guru, tetapi tidak saling membantu ketika menjalani kuis, sehingga setiap siswa harus menguasai materi yang diberikan (Slavin, 1995).

Menurut Roger dan David Johnson (dalam Rusman, 2012) ada lima unsur

dasar dalam pembelajaran kooperatif, yaitu sebagai berikut: (1)Prinsip ketergantungan positif (positive interdependence), (2) Interaksi tatap muka (face to face promotion interaction), (3) Partisipasi dan komunikasi (participation communication), (4) Evaluasi proses kelompok.

Unsur tersebut dapat djiabarkan bahwa dalam pembelajaran kooperatif, keberhasilan dalam penyelesaian tugas tergantung pada usaha yang dilakukan oleh kelompok tersebut; Tanggung jawab perseorangan (individual accountability), yaitu keberhasilan kelompok sangat tergantung dari masing-masing anggota kelompoknya. Selanjutnya memberikan kesempatan yang luas kepada setiap anggota kelompok untuk bertatap muka melakukan interaksi dan diskusi untuk saling memberi dan menerima informasi dari anggota kelompok lain. Kemudian Melatih siswa untuk dapat berpartisipasi aktif dan berkomunikasi dalam kegiatan pembelajaran. Serta menjadwalkan waktu khusus bagi kelompok untuk mengevaluasi proses kerja kelompok dan hasil kerja sama mereka, agar selanjutnya bisa bekerja sama dengan lebih efektif.

\section{Langkah-langkah STAD}

Langkah-langkah penerapan dalam model pembelajaran kooperatif tipe STAD yang diterapkan dalam penelitian ini adalah 6 langkah sebagai berikut: (1) pembagian kelompok, (2) penyampaian materi, (3) diskusi kelompok, (4) pemberian kuis /pertanyaan, (5) penyimpulan, (6) pem-berian penghargaan (Wibowo, 2016).

Pembagian kelompok dengan cara membagi siswa menjadi beberapa kelompok yang setiap kelompoknya terdiri dari 4-5 siswa yang memprioritaskan heterogenitas (keragaman) kelas dalam prestasi akademik, gender/jenis kelamin, ras 
atau etnik. Fungsi utama dari tim yang heterogen ialah memastikan bahwa semua anggota dapat belajar dengan baik. Di dalam suatu tim, ada pembagian tugas untuk setiap anggotanya. Hal ini menyebabkan tiap anggota bergantung satu sama lain dalam menyelesaikan permasalahan yang diberikan. Tim bermanfaat bagi siswa terutama anggotanya. Di dalam suatu tim, siswa akan saling menghargai, tumbuh rasa percaya diri, penerimaan terhadap anggota kelompok yang kurang secara akademik, dan perasaan memiliki atas tim tersebut.

Penyampaian materi dari guru yaitu proses pembelajaran dalam kegiatan presentasi, guru menggunakan media, demonstrasi, masalah nyata yang terjadi dalam kehidupan sehari-hari dan menyampaikan tugas ataupun pekerjaan yang harus dikerjakan disertai cara-cara untuk mengerjakannya. Kegiatan belajar dalam tim (diskusi kelompok) akan terlaksana ketika siswa belajar dalam kelompok yang telah dibentuk dan guru menyiapkan lembar kerja sebagai pedoman untuk melaksanakan kerja kelompok sehingga semua anggota menguasai dan memberikan kontribusi hasil pemikiran untuk dipresentasikan. Selama kelompok bekerja, guru melakukan pengamatan, memberikan bimbingan, dorongan dan bantuan apabila diperlukan oleh siswa. Kerja tim dalam kelompok ini merupakan ciri terpenting dari STAD.

Kuis (Evaluasi) dilakukan oleh Guru dengan cara mengevaluasi hasil belajar melalui pemberian kuis tentang materi yang dipelajari dan melakukan penilaian terhadap presentasi yang dilaksanakan di akhir pertemuan dari hasil kerja masingmasing kelompok. Siswa diharapkan dapat menyelesaikan kuis secara individu untuk menjamin siswa agar dapat bertanggung jawab pada diri sendiri dalam memahami pelajaran.

Penghargaan prestasi tim atau rekognisi tim dengan cara guru memeriksa hasil kerja siswa dan diberikan angka dengan rentang 0-100 setelah pelaksanaan kuis. Guru memberikan penghargaan atas keberhasilan kelompok yang memperoleh nilai tertinggi setelah selesai pemeriksaan hasil kerja siswa. Misalnya apabila suatu tim telah mengumpulkan skor paling banyak di kelas tersebut maka mereka mendapatkan penghargaan. Penghargaan tidak harus berupa materi. Penghargaan juga dapat diberikan dalam bentuk nilai tambahan atau hal non materi lain (Rusman, 2012).

\section{Kelebihan dan Kelemahan STAD Kelebihan STAD}

Menurut Rusman (2012) berdasarkan karakteristiknya ialah: setiap siswa memiliki kesempatan untuk memberikan kontribusi yang substansial kepada kelompoknya, dan posisi anggota kelompok adalah setara, menggalakkan interaksi secara aktif dan positif dan kerjasama anggota kelompok menjadi lebih baik, membantu siswa untuk memperoleh hubungan pertemanan lintas rasial yang lebih banyak, siswa memiliki dua bentuk tanggung jawab belajar. yaitu belajar untuk dirinya sendiri dan membantu sesama anggota kelompok untuk belajar. Menurut Isjoni (2010) Kelebihan STAD adalah melatih siswa dalam mengembangkan aspek kecakapan sosial di samping kecakapan kognitif dan peran guru juga menjadi lebih aktif dan lebih terfokus sebagai fasilitator, mediator, motivator dan evaluator. 
Selanjutnya menurut Herdian (2009) model pembelajaran STAD mempunyai beberapa keunggulan, antara lain sebagai berikut: semua anggota kelompok wajib mendapat tugas, ada interaksi langsung antar siswa dengan siswa dan siswa dengan guru, siswa dilatih untuk mengembangkan keterampilan sosial, mendorong siswa untuk menghargai pendapat orang lain, dapat meningkatkan kemampuan akademik siswa dan melatih siswa untuk berani bicara di depan kelas.

\section{Kelemahan STAD}

Menurut Khusna (2011) kelemahan STAD adalah: pembelajaran menggunakan model ini membutuhkan waktu yang relatif lama, dengan memperhatikan tiga langkah STAD yang menguras waktu seperti penyajian materi dari guru, kerja kelompok dan tes individual/kuis, karena rata-rata jumlah siswa di dalam kelas adalah 45 orang, maka guru kurang maksimal dalam mengamati belajar kelompok secara bergantian, guru dituntut bekerja cepat dalam menyelesaikan tugastugas yang berkaitan dengan pembelajaran yang telah dilakukan, antara lain koreksi pekerjaan siswa, menentukan perubahan kelompok belajar, memerlukan waktu dan biaya yang banyak untuk mempersiapkan dan kemudian melaksanakan pembelajaran kooperatif tersebut, membutuhkan waktu yang lebih lama untuk peserta didik sehingga sulit mencapai target kurikulum, membutuhkan kemampuan khusus guru sehingga tidak semua guru dapat melakukan pembelajaran kooperatif, menuntut sifat tertentu dari peserta didik, misalnya sifat suka bekerja sama.

\section{Hasil Belajar Siswa dengan Menggunakan STAD}

Hasil belajar siswa pada hakikatnya adalah perubahan tingkah laku sebagai hasil belajar dalam pengertian yang lebih luas mencakup bidang kognitif, afektif, dan psikomotorik (Sudjana, 2009). Selain itu menurut Dimyati (2006) hasil belajar merupakan hasil dari suatu interaksi tindak belajar dan tindak mengajar. STAD dapat diterapkan di SD, SMP, SMA sampai Perguruan Tinggi. Dengan menerapkan STAD sesuai dengan langkah-langkah STAD diatas, STAD dapat meningkatkan hasil belajar siswa.

Hal tersebut didudukung penelitian yang dilakukan oleh Nuryanti (2014) yang menunjukkan bahwa penerapan model STAD sesuai dengan karakteristiknya dan dikemas dalam skenario pembelajaran yang tepat pada pembelajaran matematika dapat meningkatkan hasil belajar siswa secara optimal yang ditunjukkan melalui tes hasil belajar siswa. Penelitian sebelumnya oleh Cahyanto (2013) juga menunjukkan bahwa penerapan model pembelajaran kooperatif tipe STAD dapat membantu siswa untuk mempelajari mata pelajaran matematika materi menentukan volume tabung, meningkatakan aktivitas guru dan siswa serta meningkatakan hasil belajar siswa.

Peningkatan hasil belajar siswa dapat terjadi karena model pembelajaran kooperatif tipe STAD adalah salah satu upaya guru untuk mencapai aspek-aspek pemahaman konsep, dan lainnya yang mendorong siswa untuk aktif bertukar pikiran dengan sesamanya dan memahami suatu materi pelajaran sehingga hasil belajar siswa dapat meningkat. Selain itu model pembelajaran kooperatif tipe STAD jika 
diterapkan dengan baik dan benar sesuai dengan prinsip dan langkah-langkah yang telah disebutkan, dapat meningkatkan kualitas pembelajaran siswa dan juga meningkatkan hasil belajar siswa. Oleh karena itu guru harus memahami esensi pembelajaran dengan menggunakan STAD agar pembelajaran dapat terlaksana secara efektif. Dengan harapan, kualitas pembelajaran dan hasil belajar siswa akan meningkat.

\section{KESIMPULAN}

Model Pembelajaran coperatif tipe STAD merupakan pendekatan Cooperative Learning yang menekankan pada aktivitas dan interaksi diantara siswa untuk saling memotivasi dan saling membantu dalam menguasai materi pelajaran guna mencapai prestasi yang maksimal. STAD memiliki lima prinsip yaitu, (1)Prinsip ketergantungan positif (positive interdependence), (2) Interaksi tatap muka (face to face promotion interaction), (3) Partisipasi dan komunikasi (participation communication), (4) Evaluasi proses kelompok. Jika prinsip tersebut dapat dijalankan dengan baik maka model ini akan efektif dalam mengatifkan siswa yang berdampak pada peningkatan hasil belajar siswa.

\section{SARAN}

Guru harus memahami esensi pembelajaran dengan menggunakan STAD agar pembelajaran dapat terlaksana secara efektif. Dengan harapan, kualitas pembelajaran dan hasil belajar siswa akan meningkat. Guru juga perlu melakukan analisis terhadap pembelajaran yang akan dilakukan. Agar penerapan STAD dapat berjalan lancar.

\section{DAFTAR RUJUKAN}

Cahyanto, Puji. 2013. Upaya Peningkatan Pembelajaran Matematika dalam Menentukan Volume Tabung melalui Pembelajaran Kooperatif Tipe STAD pada Siswa Sekolah Dasar. Jurnal Penelitian Pendidikan Guru Sekolah Dasar, (Online), 1(2): 111 - 114. (http://ejournal.unesa.ac.id/index.php/ jurnal-penelitian-pgsd/article/view/2373), diakses 7 November 2016.

Dimyati., \& Mudjiono. 2006. Belajar dan Pembelajaran. Jakarta: PT Rineka Cipta.

Herdian. 2009. Model Pembelajaran STAD (Student Teams Achievement Division). (Online), (http://herdy07.wordpress.com/2009/04/22/model-pembelajaranstad-student-teams-achievement-division/), diakses tanggal 25 Oktober 2016.

Isjoni. 2010. Cooperative Learning Efektifitas Pembelajaran Kelompok. Bandung: Alfabeta. 
Iskandar, S. 2011. Pendekatan Pembelajaran SAINS Berbasis Konstruktivisme. Malang: Bayumedia Publising.

Khusna, R. 2011. Upaya Peningkatan Hasil Belajar Siswa dengan Menggunakan Model Pembelajaran Kooperatif Tipe STAD. (Online), (http://rullykhusnamakalah-model-pembelajaran-stad.html), diakses tanggal 25 Oktober 2014.

Nikmah, Erlita Hidaya, Fatchan, Achmad, dan Wirahayu, Yuswanti Ariani. 2012. Model Pembelajaran Student Teams Achievement Divisions (STAD), Keaktifan Dan Hasil Belajar Siswa. Malang: Universitas Negeri Malang.

Nuryanti, Silviani Nova., Triyono., \& Susiana, Tri Saputri. 2014. Penerapan Model Kooperatif Tipe STAD dalam Peningkatan Pembelajaran Bilangan Pecahan Siswa Kelas IV Sekolah Dasar. Kalam Cendekia PGSD Kebumen, (Online), 3(1): 9 - 16. (http://jurnal.fkip.uns.ac.id/index.php/pgsdkebumen/article /view/1604), diakses 7 November 2016.

Putrama, Ramon Sinkiriwang. 2012. Penerapan Pembelajaran Kooperatif Tipe Student Team Achievement Division (Stad) Dengan Metode Eksperimen Untuk Meningkatkan Hasil Belajar Ipa Kelas Iv/ A Sd Negeri 08 Kepahiang. Bengkulu: SD Kab. Kepahiang.

Rusman, 2012. Model-Model Pembelajaran Mengembangkan Profesionalisme Guru. Jakarta PT. Rajagrafindo Persada.

Slavin, Robert E. 1995. Cooperative Learning Theory, Research and Practice Massachusett. USA: Allymand dan Bacon.

Sudjana, Nana. 2009. Penilain Hasil Proses Belajar Mengajar. Bandung: Remaja Rosdakarya.

Wibowo, Rahmat., Wahyudi., \& Ngatman. 2016. Penerapan Model Kooperatif Tipe STAD dalam Peningkatan Pembelajaran Bangun Datar pada Siswa Kelas V SD. Kalam Cendekia PGSD Kebumen, (Online), 4(1): $1-7$. (http://jurnal.fkip.uns.ac.id/index.php/pgsdkebumen/article/view/2058), diakses 7 November 2016. 